\title{
The experience of stroke and the life of the Spirit
}

\author{
Ben de la Mare
}

J Med Ethics; Medical Humanities 2005;31:105-108. doi: 10.1136/jmh.2005.000216

In this paper, I have tried in the first instance to describe the experience of stroke, and to set my own story in the context of more general observations on strokes and on the appropriate care of stroke patients. The paper makes clear that the stroke brought my active working life to an abrupt end, but I am keen to stress that in my case at least the thinking must go on. The production of this paper offers a test case of this last proposition. The paper does not attempt to survey my whole working life (mainly as a Church of England parish priest) and its interaction with my faith, but it does try to explore some of the consequences for faith, and for prayer, prompted by the stroke.There is a personal story of sometimes bewildering complexity behind every stroke. "But why is stroke any different from other serious illness?" This paper seeks to identify some of the distinctive characteristics of strokes; but I leave it to others to answer the question more adequately. It only needs to be stated here that all strokes, in some measure, affect mental processes, sometimes profoundly; and we easily underestimate the extent to which our performance is affected by our states of mind.

Correspondence to:

Mr Ben de la Mare, 216,

Gilesgate, Durham, DH1

IQN, UK

Received

5 September 2005

Accepted for publication

22 September 2005 int am not the only stroke patient who hates the intended sympathy of: "I know just what it feels like". We have all lived before and after stroke. We know very well the effect it has on energy levels, staying power, getting things completed, appetite and zest for life, mood, and much else. For some of us, these all culminate in the effect of stroke on faith, prayer, and moral urgency. If our interlocutor has travelled all these byways of the human spirit, and others too, then perhaps he/she does know "what it feels like".

My title invites the attention of a wide range of readers. For some, who are already experts in the field, I can only offer the testimony of personal experience set alongside a more hidden and elusive human discipline. Certain stroke victims who have made good recoveries have set it all down already, in books or in interviews. One, Rosemary Sassoon, most helpfully mixes her own experience with valuable advice from experts in the field. ${ }^{1}$ Many other people lack direct knowledge or experience of this condition; and it is for them that I shall include some general information about the impact of strokes.

My brain surgeon, Peter Crawford, was a little surprised when I raised the question of "spiritual impact". He had plenty to say about the process of physical recovery; and he was even more interested in stimulating a revival of mental appetite. But he left it there. I took his point; and so I shall attempt here to begin to answer my own question. My training was in theology, which is why I believe that all pastoral ministry within the Christian church should come under the searching scrutiny of theology. That scrutiny ought to extend to cover the personal experience of the minister.

We shall begin from the trauma itself. Bad things had happened in the past, but this was something quite new. It might help if we were to speak of a brain attack. That does convey something of the violence of the impact. For it affects everything, especially that decision that has to be made: should life should go on? During that shadow time when consciousness was allowed to return, I was dimly aware of a choice still to be made: "to live or not to live". Was it as simple as that? Perhaps; perhaps not, though I do distinctly remember a period when, to me, extinction really didn't matter. The raw experience of existence was so awful. Even then, however, I could still understand my value to those who are closest to me. This may go some way to explain my reported response to the innocent question: "What shall I tell them in church tomorrow", following my restoration to consciousness. I replied: "Indestructibly hopeful". I don't remember saying this; but others have said that it's authentic, and I'd like to think that those two words brought a smile. They also offer just a hint of a life sometimes disciplined by the study of theology; and with hindsight, I suggest also that the decision not to give up might have been shaped by the words of Jesus beginning: "not my will/not what I want, but ..."

In those early days of returning awareness, and right through my two months in hospital, I seemed to be faced with the withdrawal of God. I have said to friends that "I was reduced to praying, because that was almost the only thing I could gladly do". That sounds odd, but then the circumstances were strange and unfamiliar; and bodily weakness may have made the mind more alert. Let me fill in the picture. I didn't eat for a fortnight. I couldn't read. I was uninterested in the radio, and I even lost my taste for classical music.

In spite of my immobility, however, the determination to focus mind and heart together on the task of prayer prevailed. It was a prayer of the utmost simplicity. Often, just a single word repeated. I think that it sought to drain off lingering self pity and make more room for the love of God. God's absence was real enough, but his love was conveyed through the constant care that surrounded me. There is a paradox for tidy thinkers. And now let me add another: over all 
those weeks of rehabilitation, God's providence was strongly felt, but not his presence.

I alluded earlier to other bad experiences in my life. One at least relates to the matter of this paper. Almost exactly eight years before the stroke I had become seriously ill; and on that occasion I had to endure two weeks in hospital before the doctors decided that the rigors and a violently fluctuating temperature were being caused by a heart infection (subacute bacterial endocarditis or SBE). The illness had already sapped my energy; but after two months I had to face the further blow of not getting better, once the infection had been driven out. At this point, on my first encounter with the cardiologist I was offered a drastic remedy: open heart surgery in a fortnight, with mitral valve replacement. I can still remember how this decision came to me as welcome relief but to Clare as another brutal shock.

In the early stages of this illness, I hadn't much appetite for reading or for prayer. But, on my first trip into hospital, I took with me a copy of the poems of George Herbert, and I tried to read one poem a day. My instinct must have told me that he would best nourish the spirit, when more conventional prayer dries up. When the awesome day of the operation came round, with the inevitable two hour delay, I had arrived at Obedience; and these lines leaped from the page and imprinted themselves on my memory:

O let thy sacred will

All thy delight in me fulfill!

Let me not think an action mine own way,

But as thy love shall sway,

Resigning up the rudder to thy skill.

At that critical juncture, Herbert spoke to me as one who is thoroughly at home in the language of prayer (often in the robust style of the psalms). So, once his words had sunk in, I knew that I must neither seek nor claim any special favours from God. Still, the operation was successful; and after another four months off work, I resumed the full round of my duties, until this second blow struck.

It has been stated that, after cancer and heart attacks, stroke is the third commonest killer in this country. What is less well known is that it leaves more people disabled than any other condition. It should not be difficult to think of people known to us who are clearly affected by a stroke; but few are aware that children suffer strokes, along with a thousand cases a year affecting the under thirties and some ten thousand a year among those of working age.

Stroke recovery brings with it complex, sometimes stormy moods: all in all, an intriguing psychology. So, stroke presents a varied picture, mixing visible and not so visible effects. But stroke patients will be quick to remind you of important common characteristics-for example, the loss of feeling or sensation, and tiredness. ("Tiredness becomes a fact of life". Rosemary Sassoon) Another that should not be overlooked is an often well concealed anger or frustration. To conclude these general comments, I stress that we are not only required to care for the survivors but also for the suddenly bereaved. For many are killed outright by stroke, which represents a severe shock to the system. ("It is like being hit over the head with a sledge hammer." Peter Crawford)

Before we can seriously address my main theme, I need to focus on the experience of recovery from stroke, and initially this was dominated by physical recovery. Early on, I had to persuade myself to eat-sweet things were a particular problem; and even the familiar cup of tea lost its appeal, and had to be drunk in the hope that its charms would return. Throughout the first six months I battled hard to regain mobility. Once home, my regular visits to the neurophysiotherapist played a crucial role; before that, equally important, was the help from the hospital physiotherapist. They made sure that the physical structure was put in the way of best functioning. Therefore going for short walks, twice a day to begin with, was more than mere bodily exercise. Stroke patients with potential for improvement thrive on perceptible signs of progress. ("Last week I walked a mile.") Equally, we are wise to fear those who talk knowingly about our impending arrival at a "plateau". Both patient and carer have to resist the very idea of a plateau; instead, they must foster the ambition to go on getting better-whatever that means precisely.

My first conscious encounter with the consultant neurosurgeon marked a critical moment in my recovery. This was four months on and after two months back at home. He was watching me closely, more closely than I realised; and in response to my enthusiasm for walks, the effect of his comment was "Yes-but! To what end? Where is the mental stimulation?" He had caught me on the raw, and I knew it. So, a whole new field of endeavour opened up before me; and, after another two years, I am more than ever determined to look for new challenges and to discover areas of life with which I can engage effectively. With reduced mobility and limits on energy, thinking and writing play an important role in my daily routine; and often a heavy mood limits the fruitful time, especially for the very physical activity of writing.

After that meeting with the surgeon, I began deliberately to read more demanding books. I tried to make myself write more letters; but I still find this surprisingly difficult, as well as the routine of keeping on top of communications in general. I am shocked that tiredness can provoke the previously unheard "Oh, I can't be bothered". Good things, however, have been achieved during this past year: a lecture on my grandfather, the poet, has been written up. A paper on George Herbert has been revised and, more amazing, I have written and delivered a new paper on Herbert to a conference. So, I begin to realise that each of these bursts of mental toil have offered me targets that I can achieve; and, more importantly, they have given me possible evidence of the life of the Spirit reviving. The testing of my spirit is made clearer, when I offer this summary: after a year of recovery and rehabilitation, I had to cope with retirement after thirty seven years mainly in parish ministry. For the two months before I retired, I went through the motions, doing only "light duties", which has to mean "doing just what you want to do". Retirement came as a huge relief; but it was not total.

Thanks to the generous attitude of the principal of my college, an avowed agnostic, I was enabled to continue in part time chaplaincy among students. This gave me the sense of a continuing pastoral role, just when I had to let go of my established position; and it was a time when reading and writing did not come easily, but sociability was returning. Since then, much has changed in my condition. I am ready now to bring my chaplaincy to an end. This continuing of a small piece of work has also had a part to play in understanding the life of the Spirit. In such a secular institution, you might well ask: "Where is God in this set up?" To me, God has shown himself as the giver of inner freedom. Being somebody, and yet in institutional terms rather an unimportant cog, has helped me to keep my eye on God. The unfulfilled potential of the role has strengthened faith, which is never the worse for a sharp dose of self knowledge.

We return to weighing up the testing that followed retirement. Its severity only struck us when, after a six week extension, we finally moved house in mid-January. We were lucky to be moving less than a mile across the centre of Durham. At the beginning, we had to pick our way around some hundred and fifty packing cases, many of them laden with books! Some of our friends thought that we would never get them all opened; but we did. We more or less put the new 
house in order in the first four months, in spite of the distraction of having to complete the clearance of our very spacious vicarage, in which we had lived for more than twenty years. I don't really know how we did it. I had so little energy; and at first, so little strength. I couldn't leave everything to Clare; but we should never underestimate the potential of collective will power, even though it has its dangers.

This dramatic conclusion to the year of my stroke may seem to focus chiefly on physical testing; but that only tells half the story. For I came to realise that this great upheaval in my life, but also in our life together, had much to say about the life of the Spirit. An unsought break in my life's pattern did not provoke a spiritual crisis; but it did make me face the reality of change, and gave me glimpses into the meaning of resurrection.

During the long weeks in hospital it was one thing to have to make myself eat; but I had also to rekindle my appetite for life, my zest, my joie de vivre. I could, and still can, be very negative. A black period would settle on me like a cloud. I had to work hard on stretching my stamina and staying power; and I needed to mix with other people. I often spoke of my need to rejoin the human race. Later, there were things like not being allowed to drive, which I accepted, reluctantly. I also became aware of a longing to make myself reconnect with God. I know it cannot be done, just like that; and yet something changed. We shall return eventually to the question of the life of the Spirit, and to the ways in which it may be reshaped by the upheaval of a stroke; but first we must hear a little more about the practical effects of recovery, and their implications.

Throughout that first year I was busy relearning some very basic skills, like walking, and sustained reading, and being sociable. These three not so random skills represent three essential strands in the rope that holds our human nature together. You may prefer to regard them simply as three facets of our human make up.

The first concerns the fact that we are embodied. In learning again how to move across a room, and then how to reappropriate the practice and the pleasure of walking, we are attending to the most basic needs of our bodies. I am more aware now than I was before the stroke of the necessity to maintain a good level of bodily health. This does not, must not, constitute an end in itself; but after a major trauma, we know all too well how much our physical form and our bodily functioning shape and influence all aspects of our human being. So, let the recovered enjoyment of walking stand for the complex realities of embodiment.

What then of intellectual activity: of the kind of thinking that might lead me back to writing? In the early months of recovery, the surgeon had helped me to accept that the activity of walking needs to be complemented by the activity of thinking. This humble word covers so much that is common to human experience, but it also has a privileged place in the work of philosophers. I am trying to find the means of setting down in words and images what belongs to everyone. Most people rightly shy away from defining ideas such as mind and intellect. I am now much more aware of the physical effort that goes with these apparently non-physical activities. For now it may be enough to say that an interest in ideas has come back, with increasing force. So, as I have been looking for new ways of testing my stamina, I have realised that thinking must lead on to writing. It may be obvious to others, but for us stroke cases, trying to find our way back into life, all that goes with thinking is much more deliberate. "Do we want to expend energy on that?" More than two years on, writing, with all the mental and physical labour it entails, has become a key activity; but it was well over a year and a half before the ability to focus my mind effectively for writing came back.
There remains a third and crucial strand, waiting to be woven into this picture of our human make up. A fragment of personal history gives us a way in. We already owned a house in Durham, but much work needed to be done on it before we could move in. The work on the new house involved both of us in the business of planning and decision. It also entailed complex and rewarding human relations. If, at this critical juncture, I had not regained the art of being a sociable creature, I would not have been much help. Instead, the urgency of the work to be done, and the need to plan and talk through a variety of different projects drew me in. In this critical hour, I had rediscovered my love and care for buildings, and the pleasure of engaging with people, which is also a hard-learned skill; and it is much more than mere sociability. I prefer to say that we are relational creatures. Our creativity, our very humanity, thrives on our engagement with others.

It can be argued that the best of our notions, that is the fruits of our mental activity, benefit from being challenged and even from being proved wrong by others. Where there is no relationality, we are truly disabled. It is like losing a limb, or being paralysed. In the early days of my recovery, random visitors were not made too welcome. They, unwittingly, showed up my need to learn again how to relate. I could only gauge its importance from the experience of having to ration my sociability. I can see now that an excuse was available: "I'm weary". But, in time, that had to be challenged and then overcome. It is not quite the same as losing your taste for sweet things; and yet, like that, it can be relearned.

There is more to be said about those so called random visitors. I knew then, and now I know better, how much care was taken in bringing visitors to my bedside. Clergy in hospital can easily be overwhelmed by well meaning colleagues, but this did not happen to me. On the contrary, some visitors sensed the need to come alongside me in my undiagnosed spiritual isolation. It is unlikely that they knew precisely what they were doing for me, but it is as though they represented God; and at the time, I would not have been thinking of there being any spiritual significance in their presence. This is what makes any talk about "the life of the Spirit" so difficult to articulate. Nevertheless, while I was going through a real experience of desolation, the reality of God was mediated to me by people. It was chiefly by their presence and by what they did; much less by what they said.

By friends and family, and by many expert carers in the hospitals, I was being made to think anew about the character of God. "If there is a God, then what is he like?" One part of me seriously doubted whether I could come up with an answer. But another voice would not let me give up; and the clue to this second voice, may be found in the unshakable conviction that I was still a Christian. I can see now that, as for other thoughtful Christians facing a crisis, it was the person of Christ himself who stood across my pathlike the angel who barred the way for Balaam's ass-saying to me: "I have been here. Don't be afraid of the darkness". The mysterious alchemy of faith must originate in a stirring of God's love; but still this rediscovery of the importance of relationality_of valuing people and being valued by them, and of being moved by the love of others to return their love-all these very human exchanges offered me a way back to God.

The stroke patient, who is trying to fight back and to join in some of the hurly-burly of so called normal life, ought to be aware of those three strands in our human make up. Most people will take them for granted, but we have had to work at them. That much applies to all who suffer a stroke, but this paper springs from the further question that began to press on me, during my apparent recovery and return to sociable life. By now, I seemed to have accepted that God is. (I hesitate 
to define the meaning of those two small words!) But this very practical question remained: "How do I reconnect with God?" For I had experienced a real severance/loss/emptiness/ vacancy. I never forgot the core language, that is the language of prayer. It is, however, one thing to be able to convince (and to comfort) others that I have an answer, and quite another to convince myself!

The passing of time is beginning to confuse my tenses. Three years have passed since my stroke. My immersion in the life of the Spirit is closer now to where it was before the stroke. Habits of thought about God have reconnected with earlier knowledge and practice; and yet the actual practice of prayer has moved on. There is more time, and there are fewer pressures; but those gains are balanced by the real loss of energy. Now I know that physical tiredness affects me to the spiritual centre of my being. So, an inner discipline requires that I learn to wait. For God? Not precisely; but I must wait for the gift of prayer. I have known what it is for this gift to seem to be withheld; but now confidence-and with it, faith-grows stronger. I am willing to wait.

In those first weeks, it was reassuring to find that I still knew my way around the spiritual classics. I would welcome the arrival in my head of lines from Mother Julian of Norwich-" All shall be well and all manner of things shall be well"; or a phrase from The Cloud of Unknowing-"short prayer pierceth heaven", or just a single, repeated word from St John of the Cross-nada, nada, nada, nada, nada ("nothing, nothing, nothing, nothing, nothing"); or even the closing words on the bookmark belonging to St Teresa of Avila-solo Dios basta. ("God alone suffices").

To my increasing surprise, and delight, this now seems to be where I want to spend my time. The day ought first to make room for my pondering the deep things of God and the real difficulty of living a recognisably Christian life; only then should I direct mind and heart to the world's mess and all its anguish. I am learning to cope with enforced retirement; and in my daily routine, I seldom need to rush around in expense of nervous energy. Instead, more solitude makes me attentive to an insistent inner voice, which asks "Are you for God". And in spite of all my agony of spirit, I hear my prompt reply "Yes!"

Out of this story of a life restored, does it make sense for us to try to locate the life of the Spirit? Part of my answer has already been given: "in solitude" and "as an unsought gift"; and we might fill that out by saying "in a setting of God's choosing". For me, however, another answer must also be offered. For, in spite of all its faults, its follies, and its failings, the Church must be the first place for me to seek evidence of the life of the Spirit. I have tested the truth of this assertion. Not only can I say with honesty that I still love the Church, but also I understand well that the Church has been good to me. Now, as time goes on, I relish more and more the recovered status of lay Christian; but even this status is qualified, since from time to time, I still enjoy the privilege of presiding at the parish communion. It is a pleasure to be just a part of a praying community again; and I greatly value those around me in a village congregation, where it is evident that Christian love and care, respect and lightness of heart are all at work.

It seems as though, after stroke, I have been stripped down-could it be to essentials, in regard to the life of the Spirit? Now I am spared most of the burdens of administration. Now, in all my engagement, and disengagement, with or from people, I shall try to give a more complete response to that inner voice. For I want to say in body, in mind and in all relations (not only human!) "Yes to God, in all the mystery of divine being"; "Yes to Jesus Christ, who is that mystery made visible", and "Yes to the Spirit of God, whose energy informs our prayer and shapes all the good in our lives". And with slowly increasing conviction, I try to say "Yes to life, in all its unexpectednesses".

To conclude: I see a little less (the bleeding affected the optic nerve); but perhaps I hear more acutely-noticeably the birds. And much that was always striking and beautiful now moves me more. "A greater intensity?" That sounds good! But when it comes to human suffering and the spoiling of the natural world, I sometimes experience a closing down of emotions. (I referred earlier to a loss of moral urgency.) Or, is that nothing to do with the consequence of stroke?

It may be relevant to this paper to report that a longstanding interest in the seventeenth century poet George Herbert seemed to be switched off for at least a year and a half; and then it came back to life, as evidenced above. (He has a phrase for every twist and turn of life: "In age I bud again".) Herbert is the master of metaphor and of the anatomy of the spiritual life; and he prompts me to make an ending with the suggestion that the life of the Spirit is a great river. It flows on with a strong current. It carries us in a certain direction, but it does not depend upon me or you. It speaks to us of the strength and the continuity of God's love for us, and for all that he has made. We may find it harder to accept that the stirring of the Spirit brings disturbance into our lives; and that includes the disturbance of death. But, uniquely in my experience, the Spirit of God takes away fear, and replaces it with love. And that I now know to be true, with a knowledge wrung from the experience of faith.

\section{ACKNOWLEDGEMENTS}

Many people have helped and encouraged me in the writing of this paper; and I wish to name four, to whom I owe special debts of thanks.

First, I thank Frances Arnold, who convened a group of her fellow students, preparing for ordination to the ministry of the Church of England, at Westcott House Cambridge, in March 2004. To them, I gave an account of this experience of stroke, which tried to focus on their needs as future clergy. Their response and my subsequent reflection made me realise that I could not keep my original title The Spiritual Impact of Stroke.

Next, Frances Dower, herself a doctor, who set up a special meeting of the counsellors group in the Anglican diocese of Newcastle at her house, to hear the Cambridge talk as a more formal presentation. The thoughtful discussion that followed persuaded me that I must consider more radical revision. The offer of publication from this journal made that all the more necessary.

I owe a special debt of thanks to Rosemary Sassoon, author of Understanding Stroke, published in 2002 by Pardoe Blacker Publishing Ltd. A mutual friend gave me a copy of this book just when I needed it. It provided me with much of the medical detail in my paper. I look forward to meeting Rosemary face to face.

Finally, there is my wife, Clare. She, more than anyone, helped me to survive the initial crisis, and to endure the slow process of recovery. She has also made it easier for me to go on and complete this task of writing and revising.

\section{REFERENCES}

1 Sassoon R. Understanding stroke. Pardoe Blacker Publishing (Blackwell's Online), 2002. 